\title{
Traces of Linguistic Imperialism Enacted through Discursive Strategies in ELT Textbooks in Indonesia
}

\author{
Ahmad Budairi \\ Monash University, Australia \\ ahmad.budairi@monash.edu
}

\begin{abstract}
Although in many educational contexts textbooks serve as the backbone of teaching, providing practical guides for teachers as well as useful references for learning progress, they could also serve as a site of struggle for many competing discourses. ELT textbooks bear particular relevance here, as they place English at the center of prominence while serving as a medium for knowledge transmission. This paper reports on part of the findings of a case study examining the exercise of dominant discourses in two ELT textbooks for high school in Indonesia. The analysis revealed that there are imbalanced power relations - enacted through such discursive strategies as foregrounding,, backgrounding and framing in two areas: topics and visuals. These strategies were understood as part of the author's attempt to preserve the hegemonic status of English and its associated dominant ideology in ways that reflect traces of linguistic imperialism. With regard to the pedagogical value of the textbooks, this paper offers some suggestions on how the textbooks could be more engaging and culturally sensitive towards learners' socio cultural context. The discussion concludes with an appeal for more balanced representation between the discourse of the third world and that of Britain in ELT textbooks in Indonesia.
\end{abstract}

Keywords: Critical Discourse Analysis, power relations, discursive strategies, power in discourse

How to Cite: Budairi, A. (2018). Traces of linguistic imperialism enacted through discursive strategies in ELT textbooks in Indonesia. English Language Teaching Educational Journal, 1(2), 49-64.

\section{INTRODUCTION}

This article reports on part of the findings from a case study of two ELT textbooks for high school level in Indonesia: Real English 2 for Grade XI and Real English 3 for Grade XII. First published in 2008 by PT. Penerbit Erlangga Publishing Company, Jakarta, Indonesia, these textbooks were designated as supplementary under the so-called 2006 Kurikulum Tingkat Satuan Pendidikan / KTSP (School Level Curriculum). The case study was conducted in 2012, during which the textbooks under investigation were being used in four prominent high schools in the special district of Yogyakarta. In 2013, the government introduced the K13 curriculum in place of the National School Level Curriculum (KTSP). However, due to a great deal of controversy surrounding the K13 curriculum, its status was declared as a pilot project, to be implemented in a limited number of schools by the newly appointed Minister of Education in 
2014. Schools were then advised to return to the 2006 School Level Curriculum. Following a cabinet reshuffle and the review of the pilot project, the K13 curriculum began its full implementation nationwide in the 2016/2017 academic year. Whether the textbooks are still used after these curriculum changes remains a subject of enquiry, particularly because since the introduction of the School Level Curriculum in 2006, schools have been allowed greater autonomy to select their preferred textbooks in addition to those prescribed by the government.

The pedagogical value of textbooks has been widely acknowledged by many scholars. Textbooks allow teachers to focus on the real work of teaching without having their energy dissipated by preparation of teaching materials (Edge \& Wharton, 1998). They can function as a map, showing the teaching progress (McGrath, 2002; Ur, 1996) and providing direction and ideas in how lessons can be delivered (Tomlinson, 2008). The other advantage of textbooks, as Sheldon (1988) outlines, is their credibility, making them more reliable than teachergenerated or in-house materials. Well-developed textbooks are designed by experts in the area, thereby assuring their pedagogical value, whereas classroom teachers in general undergo different training and in many cases their skills and knowledge are not suited to textbook production. Allwright acknowledges this:

... we need teaching materials as carriers of decisions best made by someone other than the classroom teacher, not because the classroom teacher is deficient, as a classroom teacher, but because the expertise required of materials writers is importantly different from that required of classroom teachers - the people who have the interpersonal skills to make classrooms good places to learn it (1981: 6)

While textbooks have become indispensable as a medium for transmitting knowledge in many educational contexts, they are not merely printed letters and visual images, nor just a teaching-learning resource. It is equally important to acknowledge that textbooks are socially motivated and constructed. Since they are produced within a certain social, political and cultural context, knowledge and culture presented in textbooks are not neutral but represent the interests of an individual, group or institution. Luke (1988) suggests that in any given era in the history of education, the selection of knowledge, competence and practices for transmission in school curricula is an ideological process, serving the interests of particular classes and forms of social control. In a more specific reference, Apple (1992) considers textbooks an ideological message system for the transmission of the dominant values and beliefs of a society. Within such frameworks, textbooks may be understood as not only reflecting the purpose and goals that a particular curriculum pursues, but also embodying a particular construction of the social world; particular ways of selecting and organizing the vast universe of possible knowledge (Apple, 1992). As such, textbooks might also reflect the working of power relations and ideological assertions among different interest groups and individuals that are inextricably related. 
Along the same vein, it is interesting to consider the fact that being in a globally peripheral position, Indonesia is constantly under the influence of the ideological and cultural hegemony of advanced countries. Of special importance here is the notion of Discourse Imperialism which Pennycook (1994) refers to as the expansion of certain discourses dictated by the West, mainly by the White man but, most importantly, discourses conveyed by and through the English language which guarantee the supremacy of some countries over others. He further concedes that such a discourse is the source of regular inequalities in all fields: economics, politics, education, culture and communication. English expands hand in hand with it, it is the language of "international capitalism" ( $p$. 43). Phillipson (1992) warns against the implicit ideology of Anglocentricity and English linguistic imperialism behind ELT promotion. He suggests that "linguistic imperialism refers to a particular theory for analyzing the relations between dominant and dominated cultures, specifically the way English language learning has been promoted" (p. 15) and "the tenets of ELT have ideological and structural consequences. They serve to strengthen the hold of the center over the periphery" (p. 192). William (1989) proposes the notion of "selective tradition" in which the dominance of a specific class is maintained through the selection of certain meanings and practices to be passed off as a "tradition." It is in this light that ELT textbooks may lend themselves to the analysis of power relations. Hence, it is worth investigating how the hegemonic discourses of the West and English as an international language might be constituted, produced, naturalized and circulated through the use of linguistic and other semantic features in texts such as textbooks.

Viewed from its ontological standpoint, the study of language basically involves an analysis of language as speech. It looks into different elements of speech such as sounds (phonetics and phonology), parts of words (morphology), patterned of words and phrases, sentences (syntax) and finally meaning (semantics) as the ultimate function of language. Although this kind of analysis may offer in-depth knowledge of language features, it tends to disengage language from its social context in which language is used as a means of communication. It fails to take into account such crucial questions as how language users seek to interpret meanings, become participants in a conversation and how language can be manipulated to accomplish certain goals in a communicative event. Referring to the lack of comprehensibility in the analysis of language from its linguistic features, de Beaugrande (1996) wrote :

After three decades of research on syntax, no such system of underlying patterns and rules has yet been produced for any natural language. All we have is a pile of fragments such a system might contain, but no idea how they fit together and how we can supply the rest. The problem is simple and I am convinced, unsolvable: the arrangement of words in phrases and sentences is decided only partly by syntax and partly by speakers' knowledge of the world and their society' (p.35) 
It is then impossible to analyze any given language, both spoken and written, without taking into account the various social contexts which contribute to the shaping and emergence of extensive linguistics variation of language use. This has created the need to look at the analysis of language by incorporating the language realities as used in various communicative events in society. A similar concern was echoed by Fairclough (1995b) upon his review of the contributions to the study of language made by many existing approaches such as linguistics, sociolinguistics, pragmatics, cognitive psychology and artificial intelligence. $\mathrm{He}$ pointed to the lack of consideration of language as socially determined and as being in dialectical relation with society in such approaches. He proposed to look at the concept of language as discourse, that is, language as social practice.

The term discourse can be understood in two ways. Discourse, used as an abstract noun, refers to the "language use conceived as social practice" (Fairclough, 1993, p.138). It is not only concerned with language in use, but also the pervasive and invisible sets of values, beliefs and ideas in that social circumstances. When discourse is used as a countable noun, it refers to a "way of signifying experience from a particular perspective" (Fairclough, 1993, p.138). Thus, A discursive event is an "instance of language use, analysed as text, discursive practice, social practice" (Fairclough, 1993, p.138). Discursive event, thus, refers to text, discursive practice (production and interpretation of the text), and social practice (including situational, institutional and societal practice).

While taking the aforementioned concept of discourse analysis as the starting point, this research seeks to employ a further version of discourse analysis: Critical discourse analysis (CDA). As the word 'critical' suggests, in principle, CDA is concerned with studying and analyzing written and spoken texts to reveal the discursive sources of power, dominance, inequality and bias (van Dijk, 2001). A rather similar definition is provided by Fairclough (1995a) who considers the aim of CDA as "to systematically explore often opaque relationships of causality and determination between (a) discursive practices, events and texts, and (b) wider social and cultural structures, relations and processes; to investigate how such practices, events, and texts arise out of and are ideologically shaped by relations of power and struggles over power, and to explore how the opacity of these relationships between discourse and society itself is a factor securing power and hegemony." (p.132)

Theoretical frameworks of CDA have been proposed by different scholars, each with their respective emphasis on different aspects, attribution and levels of analysis of discourse. However, they all are essentially concerned with the same question of how language and society are dialectically related and how such relation is reflected through the use of language as social practice. As van Dijk (2001) points out, "CDA is not a specific direction of research" and therefore "it does not have a unitary theoretical frame."(p.353). However, he further asserts that "given the common perspective and the general aims of CDA, we may also find overall conceptual and theoretical frameworks that are closely related."(p.353) Fairclough and Wodak (1997: 271-80) suggest that in general, CDA deals with the linguistic characteristics of social and cultural process. It 
adopts a critical approach to social problem in its endeavor to make explicit power relationships which are frequently hidden. It conceives power relations as discursive and as such, it seeks to explain how social relations of power are exercised and negotiated in and through discourse. CDA considers discourse as constituting society and culture. This suggests that every instance of language use makes its own contribution to reproducing and transforming society and culture, including relations of power. CDA considers discourse as ideological and hence, an analysis of ideological discourse must extend beyond texts to also consider the discursive practice of how the texts are interpreted and received and what social effects they have. Discourse operates within historical terms in a sense that texts acquire their meanings by being situated in specific social, cultural and ideological contexts, time and space. (Wodak, 1995). Lastly, discourse is what links or mediates texts with society. Texts acquire their meanings by the dialectical relationship between texts and the social subjects. While in Fairclough's view, the mediating function is assumed by discourse practices -text production and consumption- (Fairclough,1995b), van Dijk (1995) considers it is the sociocognition -social cognition and personal cognition - that mediates between society and discourse.

\section{RESEARCH METHOD}

This study initially involved a corpus of six English textbooks for high school level in Indonesia: English Alive for Grades X and XI, English Zone for Grades X and XII, Real English 2 for Grade XI and Real English 3 for Grade XII. To approach the textbooks for this case study analysis, my initial strategy was to play the role of a typical reader who was trying to comprehend the texts in an uncritical manner. I then revisited the texts, this time critically, by raising questions about them, doing a brief comparative analysis of the six textbooks, and imagining how the texts could have been constructed differently. The focus of the analysis narrowed down to two ELT textbooks, namely Real English 2 and Real English 3, because their construction is strikingly different from the others.

The analysis of the textbooks was done under the framework of Critical Discourse Analysis (CDA). CDA is concerned with studying and analyzing written and spoken texts to reveal the discursive sources of power, dominance, inequality and bias (van Dijk, 2001). Similarly, Fairclough (1995) outlines the aims of CDA as "to systematically explore often opaque relationships of causality and determination between (a) discursive practices, events and texts, and (b) wider social and cultural structures, relations and processes; to investigate how such practices, events, and texts arise out of and are ideologically shaped by relations of power and struggles over power, and to explore how the opacity of these relationships between discourse and society itself is a factor securing power and hegemony" (p. 132). In terms of CDA as a method, Dijk (2001) acknowledges that CDA does not have a unitary theoretical framework or methodology because it is best viewed as a shared perspective encompassing a range of approaches instead of one school.

This case study therefore set out with a range of possibilities for applying the different classifications and categorizations of CDA. First, the six English 
textbooks to be researched may or may not have had the data necessary for a rigid framework of analysis to be applied. In other words, to use a predetermined framework of analysis as a point of departure would have meant to force a set of assumptions on the texts in terms of how and what to analyze. Given the unpredictability of the nature and formal properties of the textbooks being selected, it was essential to explore the textbooks to their fullest extent in search of any traces of salient features pertaining to ideological discourses and power relations, while working out the most appropriate method and technique of analysis. Consequently, this entailed a recursive process of data analysis in which new categories emerged upon further readings, and subsequently required some reshaping and modification to establish the most plausible conceptualization, categorization, and classification. The recursive process thus worked alongside the inductive analysis under the framework of the case study approach.

The early stage of the analysis entailed thematic classification and categorization of the texts. Different themes and topics were identified, classified and assigned to different thematic categories. A similar process was applied to the visual images in the textbooks. This process resulted in a set of data of texts and visual images in numbers and percentages. The data were then analyzed in terms of the macro structure of the textbooks; how the data contributed to the coherence of the texts as a whole. Next, the analysis proceeded with an examination of the texts at the micro level to look for instances of local semantics in the forms of propositions, syntactical structures, and lexicalization-instances of the use of language which contribute to the construction of the discourse of English as an international language. The next stage was to employ Huckin's (1997) analytic tools for close textual analysis at different degrees of granularity. They are foregrounding, backgrounding, and framing, Foregrounding is the prominence given to parts of a text, either by their physical placement or size or by the emphasis given them through word choice or syntactic structure. The opposite of foregrounding is backgrounding, which is the de-emphasizing of parts of a text. The ultimate form of backgrounding is omission, or leaving relevant information out of a text. Framing is the slant the author gives to a text. It is the way the content of the discourse is represented, including the speaker's perspective and others' points of view. This includes the use of visual aids such as photographs, font of headings and diagrams.

\section{FINDINGS AND DISCUSSION}

Using Huckin's framework of analysis, I applied a close textual examination of the textbooks to investigate the extent to which different discourses had been represented. I discovered that a great deal of prominence was given to the Western discourses, in particular Britain's cultural, social and political practices, whereas discourses about Indonesia and the rest of the world were largely underrepresented, resulting in imbalanced power relations. At the same time, the texts had also been constructed to establish a strong link between Britain (and the inner circle countries) with its superior practices and the absolute role and high stature of English to guarantee access to many highly valued social goods. The analysis revealed the use of such discursive strategies as 
foregrounding, framing, and visual images to construct Britain as a center of excellence. The following section presents evidence from the textbooks

\section{Foregrounding, backgrounding and framing \\ Topics}

The textbook Real English 2 consists of 10 units and each unit features different themes such as geography, earth power, agriculture, welfare, history, communication and information technology, profession, money and international relations. Within each unit, the author introduces different topics which are associated with the theme of the unit. Having examined these topics, I classified them into four thematic categories: British social practices, general knowledge, science and technology, global issues, and social practices in Indonesia and the rest of the world. The use of foregrounding in the textbooks is reflected in the way the writer gives prominence to social practices and traditions in Britain. As can be seen from Table 1, texts about British social practices form the bulk of the textbook, while only a small percentage of the textbook is allocated to description of social practices in Indonesia and the rest of the world.

Table 1.Text distribution in Real English 2

\begin{tabular}{|c|c|c|c|c|}
\hline & \multicolumn{4}{|c|}{ Thematic categories } \\
\hline & $\begin{array}{l}\text { British social } \\
\text { practices }\end{array}$ & $\begin{array}{l}\text { General } \\
\text { knowledge, } \\
\text { Science and } \\
\text { Technology }\end{array}$ & $\begin{array}{l}\text { Global } \\
\text { issues }\end{array}$ & $\begin{array}{l}\text { Social } \\
\text { practices in } \\
\text { Indonesia and } \\
\text { the rest of the } \\
\text { world. }\end{array}$ \\
\hline Units & $\begin{array}{l}1,3,4,5,7, \\
8.9,10\end{array}$ & $\begin{array}{l}1,2,3,4,6,7 \\
8,9\end{array}$ & $\begin{array}{l}1,2,6, \\
10\end{array}$ & $2,4,6,8,9$ \\
\hline $\begin{array}{l}\text { Number of } \\
\text { texts }\end{array}$ & 23 & 16 & 10 & 7 \\
\hline Percentage & $41 \%$ & $28.5 \%$ & $17.8 \%$ & $12.5 \%$ \\
\hline
\end{tabular}

The second textbook, Real English 3, shows an even more marked imbalance of text distribution. As in the case of Real English 2, the second textbook Real English 3 consists of 10 units, and each unit features different thematic titles such as economics, science and technology, politics, art and culture, society and population, trade and industry, international relations, energy, and the role of women. The distribution of texts based on thematic categories is presented in Table 2. 
Table 2.Text Distribution in Real English 3

\begin{tabular}{|c|c|c|c|c|}
\hline & \multicolumn{4}{|c|}{ Thematic categories } \\
\hline & $\begin{array}{l}\text { British social } \\
\text { practices }\end{array}$ & $\begin{array}{l}\text { General } \\
\text { Knowledge, } \\
\text { science and } \\
\text { technology }\end{array}$ & $\begin{array}{l}\text { Global } \\
\text { Issues }\end{array}$ & $\begin{array}{l}\text { Social } \\
\text { practices in } \\
\text { Indonesia } \\
\text { and the rest } \\
\text { of the } \\
\text { world }\end{array}$ \\
\hline Units & $1,2,3,4,5,7,8,9,10$ & $1,2,6,9$ & $3,5,6,8,9,10$ & $\begin{array}{l}1,4,5,6,7, \\
9 .\end{array}$ \\
\hline $\begin{array}{l}\text { Number of } \\
\text { texts }\end{array}$ & 36 & 11 & 13 & 10 \\
\hline Percentage & $51 \%$ & $15.7 \%$ & $18,5 \%$ & $14.2 \%$ \\
\hline
\end{tabular}

As reflected in Table 2, in the second textbook the description of social practices in Britain takes up half of the total text distribution, while other discourses share the rest. The pattern of foregrounding in these two textbooks suggests that a great deal of prominence is being attached to Britain and its social practices, whereas the social practices in Indonesia and the rest of the world are given less or small significance. By doing this, the author constructs Britain and its social practices as the dominant discourse in the minds of readers. The pervasive accounts of British social practices and English as an international language simultaneously function to invoke the notion of Britain as a center of excellence, and mastery of English as key to many highly valued social goods. Tables 3 and 4 show the different themes about Britain which dominate the textbooks. 
Table 3.Themes about Britain in Real English 2

\begin{tabular}{|c|c|c|}
\hline Unit & Thematic Titles & Topics \\
\hline 1 & Geography & $\begin{array}{l}\text { Weather conditions in Britain and Europe (pp. } \\
9-10) \text {. }\end{array}$ \\
\hline 3 & Culture & $\begin{array}{l}\text { The city of London (pp. 44-45), holiday in } \\
\text { London (pp. 56-57). }\end{array}$ \\
\hline 4 & Agriculture & $\begin{array}{l}\text { How British authority handles animal disease } \\
\text { (p. 73) animal inspection procedure (p. 74) } \\
\text { British government 's compensation for } \\
\text { farmers (p. 77). }\end{array}$ \\
\hline 5 & Welfare & $\begin{array}{l}\text { British Welfare system (pp. 81-82), Illegal } \\
\text { immigrants entering UK (p. 86), } \\
\text { unemployment in UK (pp. 87-88), jobs } \\
\text { allowance application, (p. 90), the influx of } \\
\text { Eastern Europe immigrants, (p. 93). }\end{array}$ \\
\hline 7 & $\begin{array}{l}\text { Communication } \\
\text { and Information } \\
\text { Technology }\end{array}$ & $\begin{array}{l}\text { Making an invitation in English (p. 132), } \\
\text { British teenage party (p. 134). }\end{array}$ \\
\hline 8 & Profession & $\begin{array}{l}\text { Poll on public perception about professions in } \\
\text { Britain (pp. 139-140), most respected } \\
\text { profession in Britain (p. 146), British lottery } \\
\text { (p. 150). }\end{array}$ \\
\hline 9 & Money & $\begin{array}{l}\text { Credit card security (p. 162), the cost of going } \\
\text { to university in Britain and Australia (pp. 163- } \\
\text { 164). }\end{array}$ \\
\hline 10 & $\begin{array}{l}\text { International } \\
\text { Relations }\end{array}$ & British protection for child education (p. 188) \\
\hline
\end{tabular}


Table 4.Themes about Britain in Real English 3

\begin{tabular}{|c|c|c|}
\hline Unit & Thematic titles & Topics \\
\hline 1 & Economics & Plain English campaign in Britain (p. 21). \\
\hline 2 & $\begin{array}{l}\text { Science and } \\
\text { Technology }\end{array}$ & $\begin{array}{l}\text { Early inventions by British scientists (pp. 27-28), } \\
\text { medical research and inventions by British } \\
\text { scientists (pp. 33-34), an interview between } \\
\text { Thomas Alfa Edison with a reporter in February } \\
1991 \text { (pp. 39-40). }\end{array}$ \\
\hline 3 & Politics & $\begin{array}{l}\text { The British Parliament (pp. 45-46), the Queen`s } \\
\text { speech at the Parliament (p. 48), The British } \\
\text { Monarch and the role of the Queen (pp. 49-50), } \\
\text { British and American election (pp. 51-52), the } \\
\text { British Prime Minister's Question Time (pp. 61- } \\
\text { 62), the Hansard reporters, (p. 62) }\end{array}$ \\
\hline 4 & Arts and Culture & $\begin{array}{l}\text { The history of Liverpool, a multicultural city and } \\
\text { the European Capital of Culture (pp. 65-66), } \\
\text { Audition at the Liverpool Institute for Performing } \\
\text { Arts (pp. 77-78), successful story of a former } \\
\text { Liverpool student (p. 82), prospectus of The } \\
\text { Liverpool Institute for Performing Arts (p. 83). }\end{array}$ \\
\hline 5 & $\begin{array}{l}\text { Society and } \\
\text { Population }\end{array}$ & $\begin{array}{l}\text { Early British Settlers in New England and } \\
\text { Australia (pp. 87-88), illegal immigrants entering } \\
\text { UK and Australia (pp. 92-93), a Somali refugee } \\
\text { boy in England (pp. 101-102). }\end{array}$ \\
\hline 7 & $\begin{array}{l}\text { Trade and } \\
\text { Industry }\end{array}$ & $\begin{array}{l}\text { Early industrialization in Britain and Asian } \\
\text { countries (pp. 134-135), British textile industry } \\
\text { (p. 136), British call centers (pp. 138-139), the } \\
\text { Royal Doulton Company, (p. 145). }\end{array}$ \\
\hline 8 & $\begin{array}{l}\text { International } \\
\text { Relation }\end{array}$ & International Rescue Corps (p. 157) \\
\hline 9 & Energy & $\begin{array}{l}\text { Power sources and Industrial Revolution in } \\
\text { Britain (pp. 171-172). }\end{array}$ \\
\hline 10 & $\begin{array}{l}\text { The Role of } \\
\text { Women }\end{array}$ & The Life Story of Lady Diana (pp. 191-192). \\
\hline
\end{tabular}

As reflected in Tables 3 and 4, the topics about Britain are selected to allow the author to foreground the positive aspects of British social practices. On the contrary, not much is said about the positive aspects of social practices in Indonesia. As can be seen from Tables 5 and 6, topics such as earthquake in Jakarta, tsunami in Aceh, ATM fraud experience, Indonesian workers as domestic servants overseas, and Indonesian endangered orang-utans represent the bleaker sides of Indonesia. 
The other seemingly positive topics such as crops grown in Indonesia, Indonesian fishing industry, Indonesian furniture export and Western company in Indonesia are nevertheless used by the author to indirectly emphasize the superiority of the West and the Center and to de-emphasize the positive aspects of Indonesia. For example, a topic such as 'crops grown in Indonesia' is presented with foregrounded elements of capitalism, hence ultimately serving the interest of the Center as an exporter of this ideology. This can be found in the sentence, "Crops such as sugar cane, spices, tea, coffee, palm oil, cocoa, rubber and tobacco all provide the country with much needed export income" (p. 66). Here, exporting crops to other (Western) countries is being framed as the primary purpose of growing crops in Indonesia.

Table 5.Topics about Indonesia in Real English 2

\begin{tabular}{|c|c|c|}
\hline Unit & Thematic title & Topics about Indonesia \\
\hline 2 & Earth's power & $\begin{array}{l}\text { Earthquake in Jakarta (p. 26), tsunami in Aceh } \\
\text { (pp. 29-30), }\end{array}$ \\
\hline 4 & Agriculture & $\begin{array}{l}\text { Crops grown in Indonesia's fertile land (p. 66), } \\
\text { Indonesian fishing industry (pp. 68-69). }\end{array}$ \\
\hline 6 & History & $\begin{array}{l}\text { History of Indonesian struggle for } \\
\text { independence (pp. 114-115). }\end{array}$ \\
\hline 8 & Professions & Job adverts (p. 148). \\
\hline 9 & Money & ATM fraud experience (p. 169). \\
\hline
\end{tabular}

Table 6.Topics about Indonesia in Real English 3

\begin{tabular}{|c|c|c|}
\hline Unit & Thematic Title & Topics \\
\hline 1 & Economics & $\begin{array}{l}\text { Indonesian craftsmen and women (pp. 10- } \\
\text { 11), Indonesian furniture export (p. 13), a } \\
\text { foreign buyer ordering furniture from local } \\
\text { workshop (p. 16). }\end{array}$ \\
\hline 4 & Arts and Culture & $\begin{array}{l}\text { Indonesia's six World Heritage sites (pp. } \\
69-70) \text {. }\end{array}$ \\
\hline 5 & $\begin{array}{l}\text { Society and } \\
\text { Population }\end{array}$ & $\begin{array}{l}\text { Indonesian workers as domestic servants } \\
\text { overseas (p. 97). }\end{array}$ \\
\hline 6 & $\begin{array}{l}\text { Environment and } \\
\text { preservation }\end{array}$ & $\begin{array}{l}\text { Indonesian endangered orang-utans (p. } \\
\text { 112), adventure holiday in Sumatra (p. } \\
\text { 121), preparation for adventure holiday in } \\
\text { Sumatra (p. 127). }\end{array}$ \\
\hline 7 & Trade and Industry & A western company in Indonesia (p. 143). \\
\hline 9 & Energy & $\begin{array}{l}\text { Indonesia's different sources of energy ( } \mathrm{p} \text {. } \\
182 \text { ). }\end{array}$ \\
\hline
\end{tabular}

Similarly, topics such as ATM fraud experience and Indonesians working as domestic helpers overseas are included as part of the discursive strategy to construct the discourse of Indonesia as a backward and less civilized country. For example, in Real English 2 (p. 26), the author uses a character named 'Mr. 
Idi Otic' to share his experience about the earthquake in Jakarta. The use of such a name for an Indonesian character is clearly condescending and reflects the binary perspectives and stereotypes long held by the West about the Third World.

In fact, in Unit 4 of Real English 3, Indonesian culture is described as mainly constituting buildings and natural sites, viewing culture as being detached and separate from the people, instead of focusing on the creative minds and ideas found in the diverse and rich traditions of different ethnic groups in Indonesia.

The dominant discourse of Britain serves more to highlight the many positive aspects of British social practices. Upon reading the texts, the audience is expected to build a mental model which links Britain with the notion of English as a key to acquiring many highly valued social goods. It is in this light that the author established a link between the dominant discourse of Britain throughout the text and the discourse of English being enacted in the texts.

\section{Visuals}

There are abundant examples in the textbooks where visual images have been used by the author to help foreground and frame Britain as a center of excellence. The images of Britain such as 'The Prime Minister speaks', 'Indian in central London', 'Shakespeare's Globe Theatre', 'London National History Museum', 'Liverpool's Historic Saint George Hall', 'The Magical Mystery Tour', 'a Job center Plus', 'A Channel Tunnel Train', 'Mr. Marsh and John' and 'Port of Dover' all contribute to the foregrounding of Britain as a center of excellence.

While images of Britain are generally positive, images of other countries like Indonesia and the rest of the world tend to be negative and bleak. Some images are even juxtaposed to provide a contrast between Britain or European countries and the Third World. For example, in the text about weather (Real English 2, p. 10), the author included two contrasting pictures: the winter in northern Europe where people enjoy ice skating and the rainy season in southeast Asia where buildings are inundated by floodwaters. It might be hard to conceive such juxtaposition as merely a matter of text illustration. Rather, it may reflect the author's discursive strategy to cast Britain in positive light while simultaneously invoking the grim picture of the Third World through the discussion of weather. One might wonder if the author could have otherwise featured a picture of rainy season in Indonesia in a much more favorable way.

A similar use of visuals to foreground the backwardness of the Third World can be found in the text about women's rights (Real English 3, pp. 192193) where the author presented two contasting pictures as text illustration. The first picture: 'A man beating women' projects the sweeping generalization that oppression against women's rights is still rampant in the Third World and that the same never happens in the West. By contrast, the second picture: 'British girls receive their exam results' highlights absolute protection and respect for women's rights, which guarantees them equal opportunities to pursue the best education. 


\section{Recommendations for pedagogical values}

In this section I would like to recommend some modifications to the textbooks under investigation. First the reading texts, which are mostly bland and unimaginative. The inclusion of approximately two to four reading texts in each chapter is something to be applauded, especially if it can lead to extensive reading. However, as the texts are organized around a chapter topic, there is not much variation of register and genre, and some are too technical and Britishspecific to engage readers. For example, Chapter 2 of Real English 2 includes five reading texts of different length which discuss the British political system. They are 'The British Parliament' (pp. 45-46), 'the Queen's speech at the Parliament' (p. 48), 'the British Monarch and the role of the Queen' (pp. 4950), British and American election, (pp. 51-52), the British Prime Minister's Question Time, (pp. 61-62), and 'The Hansard reporters' (p. 62). It is worth questioning whether all of these topics are appealing and familiar to high school students in Indonesia. Similar tendencies in the two textbooks can be seen in Tables 3 and 4 . There is a lack of attention given to the role of fiction as a way to engage learners in the pleasures of reading, and help them develop a reading habit. The inclusion of fiction in the textbooks is likely to cater for learners' affect and imagination, which in turn would make learning more interesting and engaging.

In the same vein, it might be worth considering incorporating a variety of cultures into the course books. In this regard, Bao (2006), suggests a number of reasons for the inclusion of international culture in course books. Among other things is the fact that English has become the language of the multicultural world. $\mathrm{He}$ argues that learners need to have a reasonable understanding of the sociocultural views of both native and non-native speakers of English, to enable them to become successful communicators, receptive to different interpretations of world views. Another kind of improvement can be made to the level of familiarity of topic contents, striking a balance between novelty and familiarity. As suggested by Bao (2016), good materials utilize learners' individual knowledge. As the reading texts are predominantly about the discourse of Britain and the West, learners are barely given a chance to relate to their own cultural resources. For example, topics like 'The Hansard reporters' (Real English 3, p. 62), and 'Cyclone Hardy' (Real English 2, p. 15) are likely to be alienating and boring for eleventh and twelfth grade students. The same is true of a speaking task in Real English 2 (p. 14) which asks learners to work in pairs to make up a dialogue in which one of them gives advice to the other about staying healthy during a visit to European countries. Obviously, the task could be very difficult for learners who have never been abroad or lived in such countries. Thus, it is important that learners are given a chance to utilize their personal knowledge in communication tasks; textbooks might then be more stimulating and engaging, both affectively and intellectually. 


\section{CONCLUSION}

The analysis of the two textbooks has strongly suggested the presence of imbalanced power relations enacted through discursive strategies. The textbooks' author has constructed the texts in a subtle way to propagate the superiority of the Western tradition and its contemporary practices. We could see how the discourse of Britain is socially constructed and produced to be circulated and consumed by the public, and in particular students. The two textbooks are laden with sprawling portrayals of the superior practices and values known in Britain (and the West). The discursive strategies such as foregrounding and framing enacted throughout the textbooks could be understood as part of the author's strategy to control the audience's reaction to the text. The author of these textbooks applied constraint on content to achieve his goal: to promote and preserve the dominance of the West over the periphery countries like Indonesia. It is at this stage of discursive process that we begin to see the truth of the selective tradition: that the selection of certain meanings and practices to be emphasized is part of hegemonic practices by the more dominant class (William, 1989) and how textbooks serve as an ideological messsage system for trasmitting the dominant values and beliefs of society (Apple, 1992). This reminds us of the notion of Discourse imperialism (Pennycook, 1994) and linguistic imperialism (Philipson, 1994) where the expansion of English also comes with the propagation of its many highly valued social and economic benefits that it brings so as to help expand international capitalism through ELT industry.

It is also interesting to see how power relations may have come into play in the case of the textbooks under investigation. Given the author's background (Peter James, a native Briton with a postgraduate certificate in ELT), we could imagine the power he assumed, generated both from his credentials, especially his being a native speaker, as well as the high stature of English as a foreign language in Indonesia. This is perhaps one of the reasons why the books were able to meet the requirements of being prescribed as supplementary textbooks. This study provides a glimpse of how the dominant, powerful inner circle countries have positioned peripheral countries like Indonesia; how they produce values associated with Britain to be consumed, circulated and naturalized. In all of these instances, we are reminded that literacy practice is always inextricably linked to cultural and power structures in society (Street, 1993). The textbooks under investigation have not, to a large extent, done justice to the discourse of the third world - by giving undue prominence to the discourse of Britain as a center of excellence with many highly valued social goods. 


\section{REFERENCES}

Allwright, R. (1981). What do we want teaching materials for? ELTJ, 36(1), pp. 5-18.

Apple, M.W. (1992). The text and cultural politics, Educational Researcher, 21, pp. 4-19.

Bao, D. (2016). Improvement in today's ELT materials development. In Azarnoosh, M, Zeraatpishe, M, Faravani, A, \& Kargozari, H.R (Eds) Issues in material development. pp. 193-205. Rotterdam: Sense Publishers.

Bao, D. (2006). Developing materials for local markets: Issues and consideratio ns. In J. Mukundan (ed.) Readings on materials II pp. 52-76. Selangor: Pearson Longman.

Beaugrande, R. de. (1996). The story of discourse analysis. In Teun van Dijk (Ed.), Introduction to Discourse Analysis (pp. 35-62). London: Sage

Edge, J. \& Wharton, S. (1998). Autonomy and development: living in the materials world. In B. Tomlinson (Ed.), Materials development in language teaching. pp. 295-310. Cambridge: Cambridge University Press

Fairclough, N. (1995a). Critical discourse analysis. London: Longman

Fairclough, N. (1995b). Media discourse. London: Edward Arnold

Freeman, D. (2014) Reading comprehension questions: The distribution of different types in global EFL textbooks. In English language teaching textbooks: Content, consumption,production. pp. 72-110. Basingstoke: Palgrave Macmillan

Huckin, T.N. (1997). Critical discourse analysis. In T. Miller (Ed.) Functional approaches to written texts: classroom applications. pp. 78-92. Washington, D.C.: United States Information Agency.

Luke. A. (1988). Literacy, Textbooks and Ideology: postwar literacy instruction and the mythology of Dick and Jane. Cambridge: Polity Press

McGrath, I. (2002). Materials Evaluation and Design for Language Teaching. Edinburgh: Edinburgh University Press

Pennycook, A. (1994). The Cultural Politics of English as an International Language. Essex: Longman 
Street, B. (Ed.) (1993). Cross cultural approaches to literacy. Cambridge: Cambridge University Press

Sheldon, L. (1988). Evaluating ELT textbooks and materials. ELTJ, 42(4), pp. $237-46$

Tomlinson, B., Dat, B., Masuhara, H. and Rubdy, R. (2001). EFL courses for adults. ELT Journal, 55(1), pp. 801-101.

Tomlinson, B. (2008). English language learning materials: A critical review. London, UK: Continuum.

Ur, P. (1996). A course in language teaching: Practice and theory. Cambridge: CUP.

Van Dijk, T.A. (2001). Critical discourse analysis. In D.Tannen, D. Schiffrin \& H. Hamilton (Eds.), Handbook of Discourse Analysis. pp. 352-371. Oxford: Blackwell.

Williams, R. (1989). Hegemony and the selective tradition. In S.C. De Castell, A. Luke \& C. Luke (Eds) Language, authority and criticism: readings on the school textbooks. pp. 56-60. London: Falmer Press.

Wodak, R. (1995). Critical linguistics and critical discourse analysis. In Verschuren, J., Ola-Ostman, J. and Bloomaert, J. (Eds.), Handbook of pragmatics, Amsterdam, Netherlands: John Benjamins, (204-210). 